\title{
An Examination of the Relationship between Mothers' Self-Efficacy Levels and Children's Psychological Problems and Psychosocial Developments
}

\begin{tabular}{ccc}
\hline $\begin{array}{c}\text { Article Type } \\
\text { Research }\end{array}$ & $\begin{array}{c}\text { Received Date } \\
13.11 .2020\end{array}$ & $\begin{array}{c}\text { Accepted Date } \\
27.05 .2021\end{array}$ \\
Fatih Aydoğdu* $^{*}$ & & Burçin Aysu $^{* *}$ \\
Neriman Aral $^{* * *}$ & & Figen Gürsoy $^{* * * * *}$
\end{tabular}

\begin{abstract}
This research was intended to predict the self-efficacy of mothers, and the psychiatric problems and psychosocial development of childrenaccording to some variables, to determine whether there is a relationship between maternal self-efficacy and children's psychiatric problems and psychosocial development. Mothers with one-three-year-old children and who refered to Family Health Centers in Erzincan, constitute the universe of the research. Also, the sample of the research consists of 128 mothers who applied to four Family Health Centers randomly selected from Family Health Centers located in Erzincan city center. In the study, self-efficacy of mothers were stated with the Self-Efficacy Scale in Parenting Skills, and the determination of children's psychiatric symptom severity and psychosocial development problems with the Social and Emotional Assessment Scale. Correlation and regression analysis were used to evaluate the data. As a result of the research; it was determined that there was a negative and weak relationship between the self-efficacy levels of the mothers and the psychiatric symptom severity levels of the children, and there was a positive and weak relationship between the self-efficacy levels of the mothers and the psychosocial development levels of the children. It was also found that selfefficacy was a significant predictor of both children's psychiatric symptoms and psychosocial developments. In addition, only education level was found to be a meaningful predictor of mothers' self-efficacy level.
\end{abstract}

Keywords: Self-efficacy, psychiatric symptoms, psychosocial development, infant, child.

\footnotetext{
${ }^{*}$ Corresponding Author: Assistant Professor, Erzincan Binali Yıldırım University, Health Services Vocational School, Department of Chid Department, Erzincan, Turkey. E-mail: faydogdu@erzincan.edu.tr, https://orcid.org/0000-0001-5123-0824

${ }^{* *}$ Assistant Professor, Ankara Yıldırım Beyazıt University, Faculty of Health Sciences, Department of Child Development, Ankara, Turkey. E-mail:burcinaysuu @ gmail.com, https://orcid.org/0000-0003-3881-191X

${ }^{* * * *}$ Prof. Dr., Ankara University, Faculty of Health Sciences, Department of Child Development, Ankara, Turkey.

E-mail: aralneriman@gmail.com, https://orcid.org/ 0000-0002-9266-938X

${ }_{* * * * *}$ Prof. Dr., Ankara University, Faculty of Health Sciences, Department of Child Development, Ankara, Turkey.

E-mail: gursoy.f@gmail.com, https://orcid.org/0000-0002-6199-4024
} 


\title{
Annelerin Özyeterlik Düzeyleri ile Çocukların Pskiyatrik Belirti Şiddeti ve Psikososyal Gelişim Sorunları Arasındaki İlişkinin İncelenmesi
}

\begin{tabular}{c}
$\begin{array}{c}\text { Makale Türü } \\
\text { Araştırma }\end{array}$ \\
\hline Fatih Aydoğdu* \\
Neriman Aral
\end{tabular}

Başvuru Tarihi

13.11.2020

\author{
Kabul Tarihi
}

27.05.2021

\begin{abstract}
$\ddot{O} z$
$\mathrm{Bu}$ araştırma, annelerin özyeterlikleri, çocukların psikiyatrik sorunları ve psikososyal gelişimlerinin bazı değişkenlere göre yordanması ve anne özyeterlik düzeyi ile çocukların psikiyatrik sorunları ve psikososyal gelişimleri arasında ilişki olup olmadığının belirlenmesi amacıyla yapılmıştır. Araştırmanın evreni, Erzincan ilindeki Aile Sağlık Merkezlerine başvuran bir-üç yaş çocuğu olan annelerdir. Örneklemi ise, Erzincan il merkezinde bulunan Aile Sağlık Merkezlerinden rasgele seçilen dört Aile Sağlık Merkezine başvuran 128 anne oluşturmuştur. Araştırmada annelerin özyeterlikleri Anne Babalık Becerilerinde Özyeterlik Ölçeği ile çocukların psikiyatri belirti şiddetleri ve psikososyal gelişim sorunlarının belirlenmesi ise Sosyal ve Duygusal Değerlendirme Ölçeği ile belirlenmiştir. Verilerin değerlendirilmesinde korelasyon ve regresyon analizleri kullanılmıştır. Araştırma sonucunda; annelerin özyeterlik düzeyleri ile çocukların psikiyatrik belirti şiddet düzeyleri arasında negatif yönde ve zayıf, piskososyal gelişim düzeyleri arasında pozitif yönde ve zayıf ilişki bulunmuştur. Özyeterliğin hem çocukların psikiyatrik belirtilerinin hem de psikososyal gelişimlerinin anlamlı yordayıcısı olduğu saptanmıştır. Ayrıca anelerin özyeterlik düzeyinde sadece öğrenim düzeyinin anlamlı yordayıcı olduğu bulunmuştur.
\end{abstract}

Anahtar Sözcükler: Özyeterlik, psikiyatrik belirti, psikososyal sorun, bebek, çocuk.

\footnotetext{
* Sorumlu Yazar: Dr. Öğr. Üyesi, Erzincan Binali Yıldırım Üniversitesi, Sağlık Hizmetleri Meslek Yüksekokulu, Çocuk Gelişimi Bölümü, Erzincan, Türkiye. E-posta: faydogdu@erzincan.edu.tr, https://orcid.org/0000-0001-5123-0824

** Dr. Öğr. Üyesi, Ankara Yıldırım Beyazıt Üniversitesi, Sağlık Bilimleri Fakültesi, Çocuk Gelişimi Bölümü, Ankara, Türkiye. E-posta: burcinaysuu@gmail.com, https://orcid.org/0000-0003-3881-191X

Pr** Pr., Ankara Üniversitesi, Sağlık Bilimleri Fakültesi, Çocuk Gelişimi Bölümü, Ankara, Türkiye.

E-posta: aralneriman@gmail.com, https://orcid.org/ 0000-0002-9266-938X

**** Prof. Dr., Ankara Üniversitesi, Sağlık Bilimleri Fakültesi, Çocuk Gelişimi Bölümü, Ankara, Türkiye.

E-posta: gursoy.f@gmail.com, https://orcid.org/0000-0002-6199-4024
} 


\section{Introduction}

Having a child with marriage is an important condition. The baby is the establishment of the family and the transition to the next cycle of the family. Although having a child and the meaning attributed to a child varies from society to society, the birth of the baby is considered the most important element for the family, which is the foundation of society (Baran and Yurteri Tiryaki, 2016). After birth, they are all living and non-living things that affect the individual in the society in which the baby lives in its outer environment. The baby's needs such as the place he lives in, every entity he / she is in contact with, feeding style, temperature, and light form its physical and social environment (Yalçın, 2010). Being a parent enables the individual to plan, give birth and care for a child in the process of becoming a parent of his child (Paul et. al., 2018). Parents make an effort to quickly adapt to a baby, who trusts them for all her physical and emotional needs right after birth, in order to give the baby the right care and establishing a positive relationship with her (Burrow Sanchez and March, 2006). Parents who have new babies are expected to make arrangements at many points in their lives such as maternity leave, breastfeeding, family leave, working life and home order. In addition to adapting to the new baby joining the family, adults in this period also need to make arrangements to support the development of the baby. Parents have many responsibilities at this point, and they are faced with problems such as the reorganization of their relationships, the responsibilities of the baby's care and development. With the increase in stress factors in the family during this period, the support received by the family is important for the re-establishment of the family balance. Pregnancy, childbirth, and the postpartum process affect the parents to a great extent, and in particular, they cause the mother to face many new physical, emotional and social situations. There are many situations in which women need to adapt, such as changes in the hormone system, physical and psychological changes, being primarily responsible for the baby's basic needs such as care and nutrition (Baran and Yurteri Tiryaki, 2016). With the birth of the child, the mother's emotions, thoughts, education and attitudes change and create a new structure. Because the human continues to grow and develop in three factors, including physiological, sociological and psychological. Therefore, psychological conditions are also effective in growth and development. It is known that the development of children who have to complete their development in difficult psychological conditions is also affected. In other words, the effect of psychological state on growth and development is great. In this respect, providing appropriate care for the child and providing an educational environment positively affect the development of the child (Yalçın, 2010).

Factors such as the mother's relationship with her own mother in her childhood, her perspective on herself as a mother and her perspective on her baby, anxiety about keeping her child alive and growing up, and whether there is a supportive environment affect the mother's rearrangement of her maternal identity. This is an important process for the child's health (Doğan et. al., 2005). Providing the mother with the right care for her baby and establishing a positive relationship with her also ensure that the baby clings to life and adapts (Burrow Sanchez and March, 2006). Infancy is a critical period for children to regulate their emotions and develop bonds with others, thanks to the relationship between mother and child (Wenzel, 2006). Parents' behavior is one of the most important indicators in determining the psychosocial risk of the baby (Teti and Gelfand, 1991).

Especially the fact that mothers have a primary importance in child development requires that their beliefs about fulfilling the competencies, duties, and responsibilities required by motherhood should be in a positive way (Coleman and Karraker, 2003). Therefore, mothers are primarily expected to have a self-efficacy regarding parenting (Coleman and Karraker, 2003; Büyüktaşkapu, 2012).

When it comes to parenting self-efficacy, parents' judgments and beliefs about their own capacities about certain duties related to the care and upbringing of their child come into play (Montigny and Lacharite, 2005). Values are explained as general principles that support beliefs. Beliefs are certain ideas that people take as true. In other words, values are abstract standards of goodness and beliefs are subjects that individuals call right or wrong (Oktay, 2018). When the literature is examined; parental self-efficacy (PSE) is a concept defined as their trust or belief in their ability to successfully carry out parenting duties (Vance and Brandon, 2017). Parental self-efficacy also affects mothers' coping skills (Paul, et. al., 2018). Self-efficacy of mothers can be determinant in child development (Jones ve Prinz, 2005) and problem behaviors (Choi et al., 2020). For self-efficacy, 
the individual must first see the ability to carry out in a competent and influential way in a specific task (Kendall and Bloomfield, 2005). If a mother with parental self-efficacy believes that her behavior can have a favourable effect on her child's development, she can solve the problems her encounters in this direction (Bandura, 1997).

Knowing and supporting mothers' self-efficacy levels can help support child development. In fact, if mothers have a baby for the first time, they may have more difficulties. At this point, it is necessary to facilitate a smooth transition to parenthood (Amin et. al., 2018). It is known that children who encounter the right approach in the early period depending on the self-efficacy levels of mothers can manage stressful situations well in the future (Burrow Sanchez and March, 2006). In the study conducted by Oliver et al. (2009), it was found that the parent's personality and parenting behaviors were associated with behavioral problems in adolescents in the long term. Although it is known that mothers 'self-efficacy levels affect children's social skills-self-care (Büyüktaşkapu, 2012), academic skills (Yuan et. al., 2016), quality of life (Kan et. al., 2020), the relationship between mothers' selfefficacy and children's psychiatric symptoms It has not been found in any research that has been examined. This research is expected to fill this gap in the field.

\section{Purpose of the Study and Research Questions}

This research was purposed in order to predict the self-efficacy levels of mothers, psychiatric problems and psychosocial development of children between the ages of one and three according to some variables, and to determine whether there is a relationship between maternal self-efficacy and children's psychiatric problems and psychosocial developments.

The research question can be stated more specifically as follow:

1) Is there a relationship between self-efficacy of mothers and children's psychiatric problems and psychosocial development?

2) Is there predict children's psychiatric problems mother's self-efficacy, number of children, education level and working status?

3) Is there predict children's psychosocial development mother's self-efficacy, number of children, education level and working status?

4) İs there predict mothers' self-efficacy levels mother's number of children, education level and working status?

\section{Method}

\section{Research Design}

This study investigated the relationship between mothers' self-efficacy levels and children's psychosocial development and psychiatric symptom levels, was designed in the relational survey model (Büyüköztürk et al., 2017).

\section{Study Group}

Mothers with one-three-year-old children, and who refered to Family Health Centers in city center of Erzincan, constitute the universe of the research. Sampling was selected from the population and 128 mothers and their children who applied to four Family Health Centers randomly selected from the Family Health Centers in city center of Erzincan and engaged in the study willingly were added. In this context, it was determined that $60.2 \%$ of the mothers incorporated into the research were 30 years old and under, $70.3 \%$ were working, $60.9 \%$ had high school and above education, and $53.1 \%$ had at least two children, $54.7 \%$ of the children were girls.

\section{Research Instruments and Procedures}

In the study, the Personal Information Form which was developed by the researchers, the Parenting Self-Efficacy Scale in Parenting Skills, and the Social and Emotional Assessment Scale (Short Form 1-3 years) were used. The Personal Information Form contains questions on the number of children, mother's working-education status and the gender of the child. 


\section{First research instrument}

The mothers' self-efficacy was evaluated with the Parenting Skills Self-Efficacy Scale developed by Emde (1989) and transcribed to Turkish by Elibol et al. (2007). The scale, which is Likert type, consists of 53 items. As a consequence of the adaptation of the scale to Turkish, the number of items was structured as 51. Parenting Skills Self-Efficacy Scale is 5-point Likert type. In the scope of the research, the Cronbach alpha worth was found to be .84 .

\section{Second research instrument}

Social and Emotional Assessment Scale (Short Form 1-3 Years) was developed by BriggsGowan and Carter (2002), and the validity and reliability work of the scale was realised by Karabekiroğlu et al. (2007). The scale is used to determine psychiatric symptom severity and psychosocial development problems in children aged 1-3 years. Of the 42 items in the scale, 31 assess psychiatric problems and 11 evaluate psychosocial development. Higher psychiatric problem score indicates higher level of psychiatric problems, and higher psychosocial development score indicates better psychosocial development. In this research, the Cronbach's alpha worth was examined, and it was found to be .77 for the psychiatric symptom severity sub-dimension and .71 for the psycho-social development sub-dimension.

\section{Data Analysis}

Throughout the process of data collection, permits were obtained primarily for the application of the measuring tools. After obtaining the permission of the ethics committee (Protocol number: 03/28, Date: 30/03/2020), the directors of the family health centers included in the study were interviewed and the goal of the study was explained, the environment where the application could be performed was determined and prepared. Data were obtained via face to face meetings with mothers who refered to Family Health Centers.

Pearson Product Moments cor analysis was realized to investigate the relationship between the self-efficacy of the mothers included in the study and the psychiatric symptoms and psychosocial development levels of the children. Pearson's correlation coefficient ranges from +1 to -1 .

The relationship value ranges from +1 to -1 . The direction and level of the relationship are determined according to the relationship value (Öztuna et al., 2008). Multiple regression analysis was realised to determine whether the self-efficacy, number of children, mother's education status and mother's working status predicted children's psychiatric symptom and psychosocial development, and whether the number of children, educational status and working status predicted the self-efficacy of mothers. Before correlation and regression analysis, normality, linearity and multiple connection problems were examined. In the analysis, it was determined that the data were normally distributed, the relationships in the binary correlation analysis between variables did not create a multiple connection problem (Topal et al., 2010).

\section{Results}

\section{Findings of the First Research Question}

\section{Table 1}

Results of the Relationship between Self-Efficacy of Mothers and Children's Psychiatric Symptom Severity Levels

\begin{tabular}{lllll}
\hline & Self-Efficacy & $\begin{array}{l}\text { Psychiatric } \\
\text { Severity }\end{array}$ & Symptom & $\begin{array}{l}\text { Psychosocial } \\
\text { Development }\end{array}$ \\
\hline $\begin{array}{l}\text { Pearson } \\
\text { Correlation }\end{array}$ & 1 &,$-275^{*}$ &, $293^{*}$ \\
\hline $\begin{array}{l}\text { Sig } \\
\text { 2(tailed) }\end{array}$ & &, 002 &, 001 \\
\hline $\mathrm{N}$ & 128 & 128 & 128 \\
\hline
\end{tabular}

As seen in Table 1, a negative relationship between the parenting self-efficacy levels of the mothers and the psychiatric symptom severity levels of the children has been found and there is a 
positive and weak relationship between the parenting self-efficacy levels of the mothers and the psychosocial development levels of the children.

\section{Findings of the Second and Third Research Question}

Table 2

Results of Analysis to Establish the Effects of Mothers' of Self- Efficacy, Number of Children, Education and Working Status on Children's Psychiatric Symptom and Psychosocial Development Levels

\begin{tabular}{|c|c|c|c|c|c|c|}
\hline Sub-dimensions & Variable & B & $\begin{array}{c}\text { Standard } \\
\text { Error }\end{array}$ & $\boldsymbol{\beta}$ & $\mathbf{t}$ & $\mathbf{p}$ \\
\hline \multirow{6}{*}{$\begin{array}{l}\text { Psychiatric } \\
\text { symptom }\end{array}$} & Constant & 40,048 & 8,424 & & 4,754 &, 000 \\
\hline & Self-efficacy &,- 095 & ,036 &,- 249 & $-2,632$ &, 010 \\
\hline & Number of children & ,276 & 1,319 &, 020 & ,209 &, 834 \\
\hline & $\begin{array}{l}\text { Mother's education } \\
\text { status }\end{array}$ &,- 992 & 1,368 &,- 072 &,- 725 & ,470 \\
\hline & $\begin{array}{l}\text { Mother's working } \\
\text { status }\end{array}$ &,- 838 & 1,400 &,- 055 &,- 599 &, 550 \\
\hline & $\mathrm{R}=, \mathbf{3 0 3}$ & $R^{2}=, 092$ & $F=2,419$ & & $\mathrm{p}<0,05$ & \\
\hline \multirow{7}{*}{$\begin{array}{l}\text { Psychosocial } \\
\text { development }\end{array}$} & Variable & $\mathbf{B}$ & $\begin{array}{l}\text { Standard } \\
\text { Error }\end{array}$ & $\boldsymbol{\beta}$ & $\mathbf{t}$ & $\mathbf{p}$ \\
\hline & Constant & ,023 & 4,285 & & ,005 & ,996 \\
\hline & Self-efficacy & ,064 & ,018 & ,321 & 3,474 & ,001 \\
\hline & Number of children & 1,234 & ,672 &, 175 & 1,836 & ,069 \\
\hline & $\begin{array}{l}\text { Mother's education } \\
\text { status }\end{array}$ & ,197 & ,699 &, 027 & ,282 &, 779 \\
\hline & $\begin{array}{l}\text { Mother's working } \\
\text { status }\end{array}$ & ,994 & ,709 &, 126 & 1,401 & ,164 \\
\hline & $R=, 356$ & $R^{2}=, 127$ & $F=3,521$ & & $\mathrm{p}<0,05$ & \\
\hline
\end{tabular}

When Table 2 is examined, it has been defined that the self-efficacy, number of children, mother's education and working status, and self-efficacy together show a relationship $\left(\mathrm{R}=.303, \mathrm{R}^{2}=\right.$, 092) with children's psychiatric symptom levels $\left(R=.303, R^{2}=, 092\right)$ and psychosocial development levels $\left(\mathrm{R}=.356, \mathrm{R}^{2}=, 127\right)$. These variables explain $9.2 \%$ of the psychiatric symptom level and $12.7 \%$ of the psychosocial development level. Considering the meaningfulness tests of the regression coefficients, it is seen that only self-efficacy, among the predictive variables, is a significant predictor on psychiatric symptoms and psychosocial development. As a result, it is possible to claim that as the self-efficacy points of the mothers increase, the psychiatric symptom scores of the children will decrease and the psychosocial development scores will increase.

\section{Findings of the Fourth Research Question}

Table 3

Results of Analysis to Determine the Effect of Mothers' Number of Children, Education Level and Working Status on Self-Efficacy Levels

\begin{tabular}{llllll}
\hline \multicolumn{1}{c}{ Variable } & \multicolumn{1}{c}{$\mathbf{B}$} & Standard Error & $\boldsymbol{\beta}$ & $\mathbf{t}$ & $\mathbf{p}$ \\
\hline Constant & 153,268 & 16,576 & & 9,246 &, 000 \\
\hline Number of children & $-4,400$ & 3,098 &,- 124 & $-1,420$ &, 158 \\
\hline Education level & 10,964 & 3,305 &, 300 & 3,317 &, 001 \\
\hline Working status & 4,899 & 3,517 &, 123 & 1,393 &, 166 \\
\hline $\mathbf{R = , 3 4 2}$ & $\mathbf{R}^{\mathbf{2}=, \mathbf{1 1 7}}$ & $\mathbf{F = 5 , 4 4 4}$ & & $\mathbf{p}<\mathbf{0 , 0 5}$ & \\
\hline
\end{tabular}

Upon the examination of Table 3 , it is seen that the number of children, education level and working status together reveal a relationship with the self-efficacy levels of the mothers $\left(R=.342, R^{2}\right.$ $=, 117$ ). These variables explain $11.7 \%$ of the self-efficacy level. Considering the meaningfulness tests of the regression coefficients, it is seen that among the predictive variables, only the education level is a significant predictor of the self-efficacy level. 


\section{Discussion, Conclusion and Recommendations}

Upon the examination of the findings, it can be said that as the self- efficacy of the mothers increases, the psychiatric symptoms of the children decrease and their psychosocial development levels increase. Mothers with high levels of self-efficacy perceive themselves as competent in matters related to the care and upbringing of their children, have a positive perception of the ability to perform effectively, their motivation and performance increase, and they become successful and emotionally well. Mothers with these skills, namely parental self-efficacy, can better support children's social development (Bandura, 1997; Kendall and Bloomfield, 2005; Montigny and Lacharité, 2005). In the study conducted by Sevigny and Loutzenhiser (2010), a relationship was found between mothers' general self-efficacy and relational functionality levels and their children's psychosocial adjustment. In another research, it was recorded that parental self-efficacy is determinant on children's goal orientation and well-being (Curelaru et al., 2020). Bojczyk et al. (2018) found that high self-efficacy in mothers created a more effective home learning experience for the child, and emphasized the link between the home learning experience and theirs vocabulary skills. Baharudin and Luster (1998) found that mothers with high family income, less children and higher marital standard provide more supportive home atmosphere, and the quality of the home environment is related to the success of their children. Binda et al. (2019) emphasized that in healthy babies at psycho-social risk, poor-quality mother-child interaction has a risk of adversely affecting the development of babies. Büyüktaşkapu (2012) found that the children of mothers with high self-efficacy perception are advanced in the field of social skills-self-care. In addition, mothers' self-efficacy levels affect children's perceived parental attitudes (Yılmaz, 2018), verbal interaction practices used by mothers (Gözübüyük, 2015), and the provision of a stimulating home environment for their children (Özdemir, 2019). Based on its effect on children, it can be said that studies on the self-efficacy of mothers will have favorable effects on children's development. In other words, studies show that mothers' self-efficacy levels affect their children's development. Findings from this study also contribute to the field in terms of showing that mothers' self-efficacy levels are determinative on their children's psychosocial development levels and psychiatric symptoms. In line with the principle that development is a whole, a deviation in one development area affects other areas of development. At the point of these studies, it is important to provide resources that will develop the knowledge and skills of the mother who has a baby, regarding the development of the baby. Examples of these resources are "to ensure that children receive education in the early years", "to provide regular education to mothers", "to deliver child follow-up to all children". The importance of early years, the importance of providing supportive stimuli during this period, and the necessity of having different experiences can be emphasized (Baran and Yurteri Tiryaki, 2016).

Sener and Cimete (2016), a weak negative correlation has found between mothers' self-efficacy and theirs democratic attitudes and their children's problem behaviors. The weakness of the relationship in this study, too, can be explained by the fact that not only mothers' self-efficacy determines the psychiatric symptoms and psychosocial development of children, but also other variables may also be effective. For example; If the marital relationship is strong before having a child, parents are usually able to find more support in their relationships after the baby is born, can estimate realistically what changes will happen in their lives regarding their responsibilities, and they are generally more satisfied with their lives after the child is born, most importantly, they can manage the responsibilities of a new baby better (Burrow Sanchez and March, 2006). For this reason, it is recommended to conduct empirical and longitudinal studies to determine the effects of mothers' selfefficacy levels on the child (Jones and Prinz, 2005). In addition, in-depth studies investigating the effects of different variables on children's psychiatric symptom severity levels can be planned. In the study conducted by Curelaru et al. (2020); it was found that mothers' high self- efficacy caused children to have high learning self-efficacy, and high learning self-efficacy caused lower depressive symptoms. In the study conducted by Teti and Gelfand (1991), it was emphasized that parenting behavior can play a substantial role in determining the psychosocial risk of the baby. Rotheram Fuller et al. (2018) found that maternal depression is effective on children's behavioral problems.

In another finding of the research; it has been found that the self- efficacy, number of children, mother's education and working status together reveal a relationship with children's psychiatric 
symptom levels and psychosocial development levels. In addition, these variables explain $9.2 \%$ of the psychiatric symptom level and $12.7 \%$ of the psychosocial development level, and it has been exhibited that only self- efficacy is a significant predictor on psychiatric symptoms and psychosocial development. Zorbaz (2018) determined that conflict with the child is a predictor of parental selfefficacy; he emphasized that when children exhibit behaviors such as aggression and breaking the rules, parents may experience conflict with their child and this may lead to a self-perception of inadequateness.

It can be said that the child's psychosocial symptom severity is influenced by the number of children, birth order, maternal education level, and parental attitudes and social support systems of the parents as well as the mother's working status. The repetitive experiences of the children with their mother, with whom they are in a primary relationship, form the relationship schemes, and these relationship schemes, which include emotional and motivational components, guide the child's future relationships. Children who are associated with timely and adequately received care have more attention control in the future, their academic skills, social and emotional development levels are higher, and they can manage stressful situations well (Burrow Sanchez and March, 2006). For this reason, when professionals working with children think that the source of various problems seen in children is family, they can also examine parents' self-efficacy levels in family interviews and offer preventive or interventional services for this (Zorbaz, 2018).

It is known that mother-father-child relationships have an crucial effect on children's social development and behaviors and that there are many variables belonging to the child and the parent that affect this (Kırman and Doğan, 2017). Derman and Başal (2013) observed at least one or more behavioral problems in $60.6 \%$ of the children included in their study, and it was found that unwanted parental attitudes were effective in children's behavioral problems. In the studies conducted; It is seen that parents' attitudes and behaviors that are pressure, discipline and overprotective have negative effects on children and adolescents (Kırman and Doğan, 2017; Sümer et al., 2010). Sümer et al. (2010) also investigated the psychological effects of parent attitudes and behaviors; he emphasized that the studies carried out in early and middle childhood are few. It can be said that this research is conducted in an age group with relatively few studies and it is an example for future studies in terms of its subject.

It can be said that the higher the education level of the mothers included in the study, the higher the self-efficacy scores. In general, every level of education aims to provide individuals with desired behaviors in society. It is thought that an individual with a high level of education will consider better adaptation to the environment. At this point, the high education level of the mother also affects her behavior towards her children in a positive way (Özyürek and Tezel Şahin, 2010). Kurt and Aslan (2020) found in their study that the self-efficacy of university graduate mothers was significantly higher than mothers who graduated from primary, secondary and high school. Mothers with a high level of education can provide the necessary stimuli to support all developmental areas of the child and can communicate with the child correctly. It can observe its development and prevent potential problems with timely measures when necessary. In addition, as children learn by modeling, mothers' behaviors and therefore their education and education levels have an important place in their perspective on life, life habits, and the development of moral values (Deniz, 2018). Education level affects parenting behavior. Yaşar Ekici (2015) found that there was a relationship between children's social skills and their mother's educational status, and stated that children whose mothers graduated from undergraduate and associate degrees had more social skills than those whose mothers were primary and secondary school graduates. Higher education graduate mothers are more sensitive to and more interested in the clue behaviors they show to reveal their children's needs (Burrow Sanchez and March, 2006).

From birth, the child, while trying to adapt to the environment, receives the greatest support from his family and therefore from the caregiver. Here, the mother has an important place. Because the mother is effective in the child's ability to express himself from early years, become a self-sufficient individual and integrate with the society. The first years of childhood are the period in which the child gains most of the behaviors and habits that will affect him throughout his life (Gürsoy and Özaslan, 
2014). The mother's ability to feel competent about parenting, her narrow belief in this issue and positive values affect the psychosocial development levels of her children positively.

At this point, the importance of increasing the perception of the mother's parental duty and motivation and performance comes to the fore. It can be said that the results obtained from this study on the self-efficacy level of mothers and psychiatric symptoms in children with normal development will guide the studies to be conducted.

Based on the research results, the following recommendations can be given:

- In-depth studies can be planned to determine the factors that affect mothers' self- efficacy levels

- Issues related to mothers' self- efficacy can be included in television programs and social platforms. Public service announcements can be created on the subject.

- Within the scope of early intervention, couples can be trained on parental self- efficacy before marriage.

- Family training activities can be used to raise self-efficacy through education. Self- efficacy levels can be increased with the training given to mothers with low educational level.

- Mixed-design studies can be conducted in which qualitative and quantitative studies are conducted on the effect of mothers' self-efficacy levels on children's psychiatric symptom severity and psychosocial development levels.

- Studies can be conducted on factors that predict children's psychiatric symptoms and psychosocial development.

\section{Limitations}

This study contributes to revealing the relationship between mothers' self-efficacy levels and their children's psychosocial development levels and psychiatric symptoms. However, the correlational relationship of the data does not enable causal interpretations of these relationships. Longitudinal studies are required to provide evidence of causal pathways between these variables. In addition, in studies on self-efficacy, the relationship of children with different developmental areas should be evaluated and more studies should be conducted with different age groups. In addition, only mothers were studied in the study, and studies including fathers can be planned. 


\section{References}

Amin, N. A. L., Tam, W. W., \& Shorey, S. (2018). Enhancing first-time parents' self-efficacy: A systematic review and meta-analysis of universal parent education interventions' efficacy. International Journal of Nursing Studies, 82, 149-162.

Baharudin, R., \& Luster, T. (1998). Factors related to the quality of the home environment and children's achievement. Journal of Family Issues, 19(4), 375-403.

Bandura, A. (1997). Self-efficacy: the exercise of control. New York: Freeman.

Baran, G. \& Yurteri Tiryaki, A. (2016). Aile Yaşam Döngüsü. Aile Yaşam Dinamiği. Ed.:Gülen Baran. pp.1-24, Ankara: Pelikan.

Binda, V., Figueroa-Leigh, F., \& Olhaberry, M. (2019). Low quality of mother-child interaction in infants at psychosocial risk is associated with risk of developmental delay. Revista Chilena de Pediatria, 90(3), 260-266.

Bojczyk, K. E., Haverback, H. R., \& Pae, H. K. (2018). Investigating maternal self-efficacy and home learning environment of families enrolled in Head Start. Early Childhood Education Journal, 46(2), 169-178.

Burrow Sanchez, J. J., \& March, R. (2006). Parent-child relationships. In Neil J. Salkind (Ed.). Encyclopedia of human development. (pp.961-963). USA: Sage Publications.

Büyüköztürk, Ş., Çakmak, E. K., Akgün, Ö. E., Karadeniz, Ş. \& Demirel, F. (2010). Bilimsel araştırma yöntemleri [Scientific research methods]. Ankara: Pegem Academy Publishing.

Büyüktaşkapu, S. (2012). Annelerin özyeterlik algıları ile 1-3 yaş çocuklarının gelişimlerinin incelenmesi. Amasya Üniversitesi Eğitim Fakültesi Dergisi [Amasya University Journal of Education Faculty], 1(1), 18-30.

Curelaru, V., Muntele-Hendreș, D., Diac, G., \& Duca, D. S. (2020). Children's and mothers' achievement goal orientations and self-efficacy: dyadic contributions to students' wellbeing. Sustainability; 12(5), 1-24.

Choi, J.K., Hatton-Bowers \& H., Shin, J. (2020). Predicting toddlers' problematic behaviors: the role of poverty, parenting, and childcare. Early Child Development and Care, 1-18.

Coleman, P. K., \& Karraker, K. H. (2003). Maternal self-efficacybeliefs, competence in parenting, and toddlers' behavior and developmental status. Infant Mental Health Journal: Official Publication of the World Association for Infant Mental Health, 24(2), 126-148.

Deniz, Ü. (2018). Gelişim. Eğitim Psikolojisi. Ed.: Neriman Aral, Tayyip Duman. pp: 32-54, Ankara: Pegem.

Derman, M. T., \& Başal, H. A. (2013). Okulöncesi çocuklarında gözlenen davranış problemleri ile ailelerinin anne-baba tutumları arasındaki ilişki. Amasya Üniversitesi Eğitim Fakültesi Dergisi [Amasya University Journal of Education Faculty], 2(1), 115-144.

Doğan, D.G., Bingöler, E.B. \& Ünal, Ö. (2005). Annelik donanımı. In, İlgi Öztürk Erdem (Ed.). Gelişimsel pediatri. pp. 57-63. Ankara: Çocuk Hastalıkları Araştırma Vakfı.

Elibol, F., Mağden, D., \& Alpar, R. (2007). Anne babalık becerilerinde özyeterlik ölçeği'nin (1-3 yaş) geçerlik ve güvenirliği [The validity and reliability of the self-efficacy scale (1-3 years old) in parenting skills]. Toplum Hekimliği Bülteni, [Bulletin of Community Medicine], 26(3), 25-31.

Gözübüyük, F. (2015). Annelerin ebeveynlik özyeterlik algıları, sözel etkileşim uygulamaları ve 1-3 yaş aralığında çocukların gelişimi. [Maternal self efficacy, mothers' verbal interaction practices and toddlers development. (Master Thesis). Maltepe University Institute of Social Sciences, İstanbul.

Gürsoy, F. \& Özaslan, H. (2014). Aile ve çocuk. Etkili iletişsim. Ed.: Abide Güngör Aytar. pp. 122-136, Ankara: Hedef.

Jones, T. L. \& Prinz, R. J. (2005). Potential roles of parental self-efficacy in parent and child adjustment: A review. Clinical Psychology Review, 25(3), 341-363. 
Kan, K., Fierstein, J., Boon, K., Kanaley, M., Zavos, P., Volerman, A. \& Gupta, R. S. (2020). Parental quality of life and self-efficacy in pediatric asthma. Journal of Asthma, 1-8.

Karabekiroğlu, K., Rodopman-Arman, A., Ay, P., Özkesen, M., Akbaş, S. \& Taşdemir, G. N. (2007). Kısa 1-3 yaş sosyal duygusal değerlendirme ölçeği (K-1/3-SDD-TR) Türkçe versiyonunun geçerlilik ve güvenilirliği. 17. Ulusal Çocuk ve Ergen Ruh Sağlı̆̆l ve Hastalıkları Kongresi, 1922.

Kendall, S. \& Bloomfield, L. (2005). Developing and validating a tool to measure parenting selfefficacy. Journal of Advanced Nursing, 51(2), 174-181.

Kırman, A. \& Doğan, Ö. (2017). Anne-baba çocuk ilişkileri: bir meta-sentez çalışması [Parent - child relationships: a meta-synthesis study]. Hacettepe Üniversitesi Sağllk Bilimleri Fakültesi Dergisi [Hacettepe University Faculty of Health Sciences Journal], 4(1), 28-49.

Kurt, H. \& Aslan, D. (2020). Okul öncesi dönem çocuğu olan annelerin öz-yeterlik, psikolojik sağlamlık ve ebeveyn tutumlarının incelenmesi [Investigation of self-efficacy, psychological resilience and parental attitudes of preschool children], Kadem Kadın Aratırmaları Dergisi [Karaelmas Journal of Educational Sciences], 6(2), 211-240.

Montigny, F. \& Lacharité, C. (2005). Perceived parental efficacy: Conceptanalysis. Journal of Advanced Nursing, 49(4), 387-396.

Oktay, A. (2018). Eğitimin Temel Kavramları. Gelişimsel Destek Programlart: Tanımlar ve Programlar. Ed. Fulya Temel, Neriman Aral, pp: 12-32, Ankara: Hedef.

Oliver, P. H., Guerin, D. W. \& Coffman, J. K. (2009). Big five parental personality traits, parenting behaviors, and adolescent behavior problems: A mediation model. Personality and Individual Differences, 47(6), 631-636.

Özdemir, G. (2019). Annelerin 3-6 yaş çocuklarına sağladıkları ev ortamının uyarıcılığı ile ebeveyn öz yeterlik düzeyi arasındaki ilişki. [The relationship between parental self-efficacy level of mothers with 3-6 years old children and the stimulation of home environment provided to their children]. (Master Thesis). Maltepe University Institute of Social Sciences, İstanbul.

Öztuna, D., Elhan, A. İ. \& Kurşun, N. (2008). Sağlık araştırmalarında kullanılan ilişki katsayıları [Correlation coefficients in medical research: review]. Türkiye Klinikleri Tip Bilimleri Dergisi [Turkiye Klinikleri Journal of Medical Sciences], 28(2), 160-165.

Özyürek, A. \& Tezel Şahin, F. (2010). Anne Baba Olmak ve Anne Babaların Çocuk Yetiştirme Tutumları. Anne Baba Eğitimi. Ed.: Tülin Güler. pp: 35-49, Ankara: Pegem.

Paul, P., Pais, M., Kamath, S., Pai, M. V., Lewis, L. \& Bhat, R. (2018). Perceived maternal parenting self-efficacy and parent coping among mothers of preterm infants-a cross-sectional survey. Manipal Journal of Medical Sciences, 3(1), 24-27.

Rotheram-Fuller, E. J., Tomlinson, M., Scheffler, A., Weichle, T. W., Hayati Rezvan, P., Comulada, W. S. \& Rotheram-Borus, M. J. (2018). Maternal patterns of antenatal and postnatal depressed mood and the impact on child health at 3-years postpartum. Journal of consulting and clinical psychology; 86(3), 218- 230.

Sener, D. K. \& Cimete, G. (2016). A program based on Social Cognitive Theory and Smith's model of health and illness and its effect on maternal self-efficacy and child behavior. Children and Youth Services Review; 64, 82-90.

Sevigny, P. R. \& Loutzenhiser, L. (2010). Predictors of parenting self-efficacy in mothersandfathers of toddlers. Child: Care, Health and Development, 36(2), 179-189.

Sümer, N., Gündoğdu Aktürk, E. \& Helvacı, E. (2010). Anne-baba tutum ve davranışlarının psikolojik etkileri: Türkiye'de yapılan çalışmalara toplu bakış. Türk Psikoloji Yazıları [Turkish Psychological Articles], 13(25), 42-59.

Teti, D. M. \& Gelfand, D. M. (1991). Behavioral competence among mothers of infants in the first year: The mediational role of maternal self-efficacy. Child Development, 62(5), 918-929. 
Topal, M., Eyduran, E., Yağanoğlu, A. M., Sönmez, A. \& Keskin, S. (2010). Çoklu doğrusal bağlantı durumunda ridge ve temel bileşenler regresyon analiz yöntemlerinin kullanımı [Use of ridge and principal component regression analysis methods in multicollinearity]. Atatürk Üniversitesi Ziraat Fakültesi Dergisi [Atatürk University Journal of Agricultural Faculty], 41(1), 53-57.

Vance, A. J. \& Brandon, D. H. (2017). Delineating among parenting confidence, parenting selfefficacy and competence. ANS. Advances in Nursing Science, 40(4), 18-37.

Wenzel, A. (2006). Postpartum depression. In Neil J. Salkind (Ed.). Encyclopedia of human development. (pp.961-963). USA: Sage Publications.

Yalçın, H. (2010). Çocuk Gelişimi. Ankara: Nobel.

Yaşar Ekici, F. (2015). Okul öncesi eğitime devam eden çocukların sosyal becerileri ile aile özellikleri arasındaki ilişkinin incelenmesi [Investigating the relationship between social skills and family characteristics of the children that attending pre-school education]. Karadeniz Sosyal Bilimler Dergisi [The Black Sea Journal of Social Science], 7(2), 1-3.

Yılmaz, G. (2018). Annelerin özyeterlik algısı ile çocuklarının algıladıkları anne tutumu arasındaki ilişkiler [The relation between perceived self efficacy of mothers' and perception of children to their mothers]. (Master Thesis). Nişantaşı University, Institute of Social Sciences İstanbul.

Yuan, S., Weiser, D. A. \& Fischer, J. L. (2016). Self-efficacy, parent-child relationships, and academic performance: A comparison of European American and Asian American college students. Social Psychology of Education, 19(2), 261-280.

Zorbaz, S. D. (2018). Ebeveyn özyetkinliğinin yordayıcısı olarak ebeveyn-çocuk ilişkisi [Child parent relationship as a predictor of parental self-efficacy]. Dokuz Eylül Üniversitesi Buca Eğitim Fakültesi Dergisi [Buca Faculty of Education Journal], (46), 144-153. 